\title{
An empirical study for measure the relative performance of banking operations
}

\author{
Ali Akbar Aminbeidokhti ${ }^{a}$, Seyyed Abdollah Heydariyeh ${ }^{\mathbf{b}}$ and Jalil Abedini ${ }^{\mathbf{b}^{*}}$
}

${ }^{a}$ Department of Management, University of Semnan, Semnan, Iran

${ }^{b}$ Department of Management, Islamic Azad University, Semnan Branch, Semnan, Iran

\section{A R T I C L E I N F O A B S T R A C T}

\section{Article history:}

Received October 19, 2011

Received in Revised form

November, 14, 2011

Accepted 4 December 2011

Available online

8 December 2011

\section{Keywords:}

Change of location-share model

Structural growth

Competitive growth

Banking sector

\begin{abstract}
Structure analysis plays an important role on increasing the efficiency of banking industry. A change in structure of business in this industry could change the profitability, significantly. The proposed study of this paper aims at structural analysis and comparative advantages for a governmental bank in a province of Semnan, Iran called Melli bank. The proposed study considers the effectiveness of four saving plans including current, loaned with no interest, short and long term based in three periods. It applies the change of location-share model, which includes provincial growth influence, structural growth and competitive growth as the determinant variables in saving rate. Findings indicate the disproportionate growth of saving rate in the Melli bank toward the other banks of the province in every 3 terms of the study. The research results show that short time saving in 2001 and 2004, loaned without interest and short term savings in 2001 and 2008, loaned without interest and long term savings in 2004 and 2008 had negative structural changes which indicate that the combination of discussed saving wasn't desirable, but other savings benefits of desirable combination.
\end{abstract}

\section{Introduction}

One of the most important factors in the economic growth and development is the existence of banks with high efficiency and health. The existence philosophy of banks is generally the mediator of their being funds, that is, it pays to resource equipment on one hand, and resource consumption and granting facilities to customers on the other hand. In other words, banking system is like the body of economic system and driving motor of economic cycle in developing countries. It plays an important role in this field, because it plays a fundamental role in financial provision economic middle term and short term programs of the country (Bendavid-Val, 1991; Blair, 1995).

One of the main operations of banking system is to attract and procure the saving payments and use them to provide the financial requirements of all kinds of economic activities of the state. In other

* Corresponding author. Tel.: +989191011808

E-mail addresses: jalil.abedini65@gmail.com (J. Abedini) 
words, banks are mediators between savers and applicants of facilities and venture to grant facilities by use of its resources and individual's savings. Banking system of the state plays an important role in economic system by possessing a main part of cashes and currency. It also has a significant influence on regulating the economic relations and decorum of society. On one hand, banks require attraction of current cash and currencies of society to become successful in implementing the other part of their duty, which is granting the bank facilities to customers by equipment of their resources. On the other hand, they require adoption of their own special methods for attraction of such savings. In other words, some factors are effective in saving attraction and the banks should be familiar and if possible, benefit of them.

Development of a bank depends at first on increasing the volume of its savings. The policies regulated in limitative and preservative way lead to delay in extension of banks. These policies and their dependant official affairs are determinant and the destination of each bank to convert the activities on saving to stagnant the state or to gradual extension or put them in the way of quick growth. A strategic approach for investigating and measuring the output of the banks, which leads to their development, is the output indexes of interest rate (Lai et al., 2011). Banking industry as an industry in financial sector confronts with quick change in new technology market, economic uncertainty, intensive competition, diverse needs of customers, and changing environment, which leads to a set of unprecedented challenges (Kumar et al., 2011; Boarnet, 1998).

One of the most important duties of financial managers is the way of providing financial resources and optimum use of these resources in achieving the organizational objectives. Therefore, research in expenditures (facilities) and resources (savings) and the resulting influences of expenditures (facilities) and resources (savings) is of too much significance for financial managers of the banks.

Shift-share analysis (Houston, 1967; Esteban-Marquillas, 1972) is an especial technique of disaggregating regional employment change in a sector of industry to determine the components of that change. The method was originally focused on the part of growth or decline in an industry, which is region-specific. The regional shift component tries to give us a measure of relative performance of the region for an industry (Fernandez \& Menendez, 2005). Stevens and Craig (1980) provided a critical review of the literature on shift-share as a forecasting technique. They identified some basic issues on the concept of shift-share and discussed some alternative and more promising uses of shiftshare as an element in more accurate methods of regional forecasting.

Resource attraction is considered as one of the main and key activities of the banks since it is, in fact, the main infrastructure of other activities and the other banking services are differently influenced by this item. Collecting and attracting all kinds of savings and its allocation for providing financial requirements of all economic activities are regarded as the most important operations of the bank. Acting in the context of saving attraction make the bank management produces revenue by applying the available resources via granting facilities and investment in different fields. Attraction of more savings and encouraging individuals in savings, which is, in fact, the origin and basis of banking activities is considered as one of the most important activities for all banks.

The vital role of the banks in discharging monetary markets and the economic procedure of each country is perfectly vivid. These monetary institutions play valuable role in their relation with people in both fields of saving acceptance and collection as well as lending to individuals and industrial and manufacturing institutions. The key factor in collecting small investments and changing them to great ones, were the banks.

Das et al. (2009) implemented data envelopment analysis to measure labor-use efficiency of individual branches of a large public sector bank with a sizable network of branches across India. They found remarkable differences in the average levels of efficiency of bank branches across the four metropolitan regions considered in this study. They expressed the concept of area or spatial 
efficiency for each region proportion to the nation as a whole. They reported that the policies, procedures, and incentives handed down from the corporate level did not fully neutralize the detrimental influence of the local work culture across different regions. Most of the potential reduction in labor expenditure appeared to be coming from possible downsizing in the clerical and subordinate staff. They also reported that operate at very low levels of labor-use efficiency and possible candidates for increased supervision and control.

The proposed study of this paper aims at structural analysis and comparative advantages for a governmental bank in a province of Semnan, Iran called Melli bank. The organization of this paper first present the proposed study in section 2, details of the finding are given in section 3 and the paper finishes with concluding remarks in section 4.

\section{The proposed study}

Saving attraction is one of the main duties of the banks by applying the abundant available funds and granting facilities and appropriate investment in different fields, which causes the banking system, produces revenue.

The policy makers of banking system require performing accurate programming in attracting more savings for the realization of this affair. With respect to discussed instances, we can find that bank's ability in attracting more savings and customer's cash is considered as one of the most important measures of performance evaluation for the success of a banking system and can proceed of their competitors by means of this ability and persistently continue their activity in present competitive environment. With respect to the fact that the banks pay similar rate of interest to customers in saving attraction and from this respect there is no significant difference among them.

Individual's savings in banks is important for two reasons, first the money individuals deposit in banks, which raises the bank's lending power, so banks can provide more loans to manufacturers and investment affairs through collected savings. It can also raise the individual's savings in the banks, reduces capital spending, which leads to a reduction in the inflation rate and, as a result, increases the people's buying power. These factors have caused the different banks to encourage people to open more saving account or increase their deposits. Nowadays, the importance of financial resource attraction is so vital for banks in this field that they there has been an intensive competition among them.

The main problem in banking and monetary system is the way of equipping financial resources and allocating and distributing in different parts of economy. In fact, the more the banking system operate more efficiently in financial resource equipment and its allocation in competitive environment, the more we can observe the reduction in manufacturing cost, improvement in manufacturing affairs and employment as well as economic growth. Otherwise, inefficiency of banking system in optimum allocation and equipment of financial resource lead to resource loss and provoking the economic stagnancy.

New fields are produced for attracting more savings and giving better and faster services to customers along with this issue and in recent decades. Banking by the use of TV, mobile and extensive use of Internet network and giving banking services such as Electronic money and cheque and everincreasing prevalence of electronic business in the arena of economic activities are some of the new businesses.

\subsection{Case study}

The proposed case study of this paper is one of the biggest and the oldest governmental bank of Iran, called Bank Melli Iran. The bank is the first national Iranian bank. The bank was established in 1927, presently has over 3300 domestic and international branches with 43,000 employees. Melli bank has 
done its best in saving attraction in banking system of the state by the use of its human and capital resources in the whole country and employees have attempted to lead the customer's savings to profitable economic activities and investments by attracting the individual trust and encourage them to save in banks. Successful commission of banking operations especially granting facilities as the most significant index of banking task is a function of resource volume and the way of its circuit.

\subsection{The proposed question}

The proposed study of this paper attempts to find the position of Semnan Melli bank on the change of share location model in four savings accounts including current, loaned without interest, short term and long term. We have gathered the necessary data for three periods of 2001/2004/2008.

\subsubsection{The research objectives}

General objectives of the paper are:

a) Structural analysis and survey of comparative advantages of Semnan Melli bank from saving point compared with other banks in the province.

b) Determining the competitive position of each township's structural part compared with other provinces.

There are other relative questions on this survey, which include the relationship between saving growth rate of the case study bank and the growth rate of other banks. It also considers the effects of concentration activities on saving account, whether the case study has any competitive advantages in attracting of savings compared with other banks in the province and finally the priorities of the bank. The results of this survey uses share-shift model discussed earlier in this paper. Let $S=\sum S_{i}$ be total provincial saving, $s_{i}$ be the provincial saving in saving location $i, t$ and $n$ be the beginning and the end year of the term, respectively. Let $N_{s i}$ be provincial growth, $i m_{i}$ be structural growth, $r s_{i}$ be competitive growth. Therefore, we have,

$$
\begin{aligned}
& n s_{i}=s_{i}^{t}\left(S_{n} / S_{t}-1\right), \\
& i m_{i}=s_{i}^{t}\left(S_{i}^{n} / S_{i}^{t}-S^{n} / S^{t}\right), \\
& r s_{i}=s_{i}^{t}\left(s_{i}^{n} / s_{i}^{t}-S_{i}^{n} / S_{i}^{t}\right),
\end{aligned}
$$

The growth rates are defined as follows,

$$
\begin{aligned}
& \left.g_{r}=\sum_{i=1}^{m} s_{i}(t+n)-\sum_{i=1}^{m} s_{i}(t)\right) / \sum_{i=1}^{m} s_{i}(t), \\
& g_{n}=\left(\sum_{i=1}^{m} S_{i}(t+n)-\sum_{i=1}^{m} S_{i}(t)\right) / \sum_{i=1}^{m} S_{i}(t), \\
& g_{r n}=\left[\sum_{i=1}^{m}\left(s_{i}(t)-S_{i}(t+n) / \sum_{i=1}^{m} s_{i}(t)\right] / \sum_{i=1}^{m} s_{i}(t),\right.
\end{aligned}
$$

where $g_{r}$ is the saving growth rate of the bank in the province, $g_{n}$ is the saving growth rate of all banks in the province and $g_{r n}$ is the proportion saving growth rate of all banks in the province, 
respectively. Let $M$ be total number of saving kinds, which includes current, loaned without interest, short term and long term. Therefore, we have,

$g_{r}=\left(g_{r}-g_{r n}\right)+\left(g_{r n}-g_{n}\right)+g_{n}$

When $\left(g_{m}>g_{n}\right)$, it means that the hypothetical growth rate is higher than the growth rate of province banks and we can conclude that the combination of the proposed saving portfolio is favorable. On the contrary, when $\left(g_{m}<g_{n}\right)$, we can conclude that the saving combination of the proposed case study is undesirable, which means that the proposed bank maintains slower growth than other banks. In case we have $\left(g_{m}=g_{n}\right)$, the saving combination of province Melli bank is the same as the other banks in the province.

$\left(g_{r}-g_{m}\right)$ : is called the resulting part of competitive advantage, if it is positive, we can say that the growth rate of the proposed case study bank is proportionate to other banks of province, and if it is negative, it does not provide any advantages.

\section{The results}

In this section, we present details of our results. Table 1 shows the implementation of our proposed study for a period of 2001 to 2004.

Table 1

The results of our proposed model from 2001 to 2004(gm=-1, gn=1.32, gr=1.32)

\begin{tabular}{|c|c|c|c|c|c|c|}
\hline Year & Description & Current & $\begin{array}{l}\text { Loan with no } \\
\text { interest }\end{array}$ & Short term & Long term & $\begin{array}{l}\text { Total } \\
\text { Saving }\end{array}$ \\
\hline \multirow{3}{*}{2001} & Province Melli bank & 48200 & 209525 & 53920 & 16878 & 328599 \\
\hline & Total banks of the province & 193732 & 956121 & 313172 & 65106 & 1556007 \\
\hline & Province Melli bank & 51954 & 302931 & 60659 & 18698 & 435202 \\
\hline \multirow[t]{5}{*}{2004} & Total banks of the province & 267705 & 1446380 & 288616 & 78265 & 2122772 \\
\hline & Provincial growth & 17557 & 80003 & 27648 & -1323 & \\
\hline & structural growth & 848 & 27432 & -31876 & 4735 & \\
\hline & competitive growth & -14650 & -14030 & 10877 & -1591 & \\
\hline & $\begin{array}{l}\text { Provincial, structure and } \\
\text { competitive growth }\end{array}$ & 3754 & 93406 & 6649 & 1820 & \\
\hline
\end{tabular}

As we can observe from the results of Table $1, g_{m}<g_{n}$, which means the combinations of the assets are undesirable during the years of 2001 to 2004.

Table 2

Values of model variables in the four saving plan (current, loaned without interest, short and long term)

\begin{tabular}{lllll}
\hline Saving item & Current & Loan with no interest & Short term & Long term \\
\hline Provincial growth & -1323 & 27648 & 8003 & 17557 \\
\hline Structural growth & 4735 & -1876 & 27432 & 848 \\
\hline $\begin{array}{l}\text { Competitive } \\
\text { growth }\end{array}$ & -1591 & 10877 & -14030 & -14650 \\
\hline
\end{tabular}

From the results of Table 2, we observe positive values for loan with no interest, short and long-term plans in provincial growth part, and, in terms of structural growth, there are some positive values in current, short and long-term plans. The competitive growth shows positive value only for loan with no interest. 
With respect to the negative values of structural growth effect about short term saving, we can say that the structural combination of provincial saving preserves lower share in savings, which benefit of higher provincial growth. Since $\left(g_{r}-g_{m}\right)$ preserves a positive value, 2.32, we can conclude that the proposed bank has some advantages compared with other banks.

\section{Table 3}

Results change of location-share model (2001-2008) (gm=-1, gn=1.61, gr=1.49)

\begin{tabular}{lllllll}
\hline Year & Description & Current & $\begin{array}{l}\text { Loan with no } \\
\text { interest }\end{array}$ & Short term & Long term & $\begin{array}{l}\text { Total } \\
\text { Saving }\end{array}$ \\
\hline \multirow{2}{*}{2001} & Province Melli bank & 48200 & 209525 & 53920 & 16878 & 328599 \\
& Total banks of the province & 193732 & 956121 & 313172 & 65106 & 1556007 \\
\hline \multirow{2}{*}{2008} & Province Melli bank & 83296 & 323586 & 62856 & 21460 & 491198 \\
& Total banks of the province & 360304 & 1700392 & 380279 & 91250 & 2557292 \\
\hline & Provincial growth & 31017 & 180151 & 41973 & 3617 & \\
& $\begin{array}{l}\text { structural growth } \\
\text { competitive growth }\end{array}$ & 10426 & -17051 & -30419 & 3161 & -2196 \\
& $\begin{array}{l}\text { Provincial, structure and } \\
\text { competitive growth }\end{array}$ & -6347 & -49039 & -2618 & 4582 & \\
\hline
\end{tabular}

Again, we can observe from the results of Table 2, $g_{m}<g_{n}$, which means the combinations of the assets are undesirable during the years of 2001 to 2008.

Table 4

Values of model variables in the four saving plan (current, loaned without interest, short and long term)

\begin{tabular}{lllll}
\hline Saving item & Current & Loan with no interest & Short term & Long term \\
\hline Provincial growth & 31017 & 180151 & 41973 & 3617 \\
\hline Structural growth & 10426 & -17051 & -30419 & 3161 \\
\hline $\begin{array}{l}\text { Competitive } \\
\text { growth }\end{array}$ & -6347 & -49039 & -2618 & -2196 \\
\hline
\end{tabular}

With respect to the positive values of provincial growth influence about all saving accounts, we can say that provincial growth share is lower than total savings of the banks located in the province.

With regarding the negative values of structural growth influence about no interest loans, we can say that structural combination of the provincial saving resulted lower share in savings. By considering the negative values of competitive growth influence in every four savings, we can say that the proposed bank of the case study of this paper has lost its share in certain saving accounts compared with other banks.

Furthermore, a positive value of $\left(g_{r}-g_{m}\right)$ means that the proposed bank of this paper has some advantages rather than the other banks in saving attraction.

Table5

Results change of location-share model (2004-2008) (gm=-1, gn=1.17, gr=1.13)

\begin{tabular}{lllllll}
\hline Year & Description & Current & Loan with no interest & Short term & Long term & Total Saving \\
\hline \multirow{2}{*}{2004} & Province Melli bank & 51954 & 302931 & 60569 & 18698 & 435202 \\
& Total banks of the province & 267705 & 1446380 & 288616 & 78265 & 2122772 \\
\hline \multirow{2}{*}{2008} & Province Melli bank & 83296 & 3235586 & 62856 & 21460 & 491198 \\
& Total banks of the province & 360304 & 1700392 & 380279 & 91250 & 2557292 \\
\hline & Provincial growth & 10635 & 104784 & 10637 & 5938 \\
& structural growth & 7336 & -51583 & 8599 & -2836 \\
& $\begin{array}{l}\text { competitive growth } \\
\text { Provincial, structure and } \\
\text { competitive growth }\end{array}$ & 13371 & -31342 & 20655 & -16949 & -340 \\
\end{tabular}


As we can observe from the results of Table $5, g_{m}<g_{n}$, which means the combinations of the assets are undesirable during the years of 2004 to 2008.

Table 6

Values of model variables in the four saving plan (current, loaned without interest, short and long term)

\begin{tabular}{lllll}
\hline Saving item & Current & Loan with no interest & Short term & Long term \\
\hline Provincial growth & 10635 & 104784 & 10637 & 5938 \\
\hline Structural growth & 7336 & -51583 & 8599 & -2836 \\
\hline $\begin{array}{l}\text { Competitive } \\
\text { growth }\end{array}$ & 13371 & -32545 & -16949 & -340 \\
\hline
\end{tabular}

Meanwhile, since $\left(\mathrm{g}_{\mathrm{r}}-\mathrm{g}_{\mathrm{m}}\right)$ preserves a positive value of 2.13, so we can conclude that the province Melli bank has advantages in saving attraction compared with other banks of the province.

\section{Conclusion}

In this paper, we have proposed a structural analysis to study the comparative advantages for a governmental bank located in a province of Semnan, Iran called Melli bank. The proposed study considered the effectiveness of four saving plans including current, loaned with no interest, short and long term based in three periods. It applied the change of location-share model, which includes provincial growth influence, structural growth and competitive growth as the determinant variables in saving rate. Findings indicated the disproportionate growth of saving rate in the Melli bank toward the other banks of the province in every 3 terms of the study. The research results showed that short time saving in 2001 and 2004, loaned without interest and short term savings in 2001 and 2008, loaned without interest and long term savings in 2004 and 2008 had negative structural changes which indicate that the combination of discussed saving wasn't desirable, but other savings benefits of desirable combination.

\section{Acknowledgment}

The authors are grateful for detailed comments of anonymous referees on earlier version of this paper.

\section{References}

Bendavid-Val, A. (1991). Regional and Local Economic Analysis for Practitioners. Westport, CT: Prager Publishers.

Blair, J. P. (1995). Local Economic Development: Analysis and Practice. Thousand Oaks. CA: Sage Publications.

Boarnet, M.G. (1998). Spillovers and the locational effects of public infrastructure. Journal of Regional Science, 38, 381.

Das, A., Ray, S.C., \& Nag, A. (2009). Labor-use efficiency in Indian banking: A branch-level analysis. Omega, 37(2), 411-425.

Esteban-Marquillas, J.M. (1972). A reinterpretation of shift-share analysis. Regional and Urban Economics, 2, 249-255.

Fernandez, M., \& A. Menendez. (2005). Spatial shift-share analysis: new developments and some findings for the Spanish case. Working Paper, 45th Congress of the European Regional Science Association.

Houston, D. B. (1967). The shift and share analysis of regional growth: a critique. Southern Economic Journal, 33(4), 577-581. 
Kumar, A., Singh, G.K., Anand, R.S. (2011). An improved closed form design method for the cosine modulated filter banks using windowing technique. Applied Soft Computing, 11(3), 3209-3217.

Lai, J.S., Cella, D., Choi, S., Junghaenel, D.U., Christodoulou, C., Gershon, R., \& Stone, A. (2011). How item banks and their application can influence measurement practice in rehabilitation medicine: A PROMIS fatigue item bank example. Archives of Physical Medicine and Rehabilitation, 92(10), 20-27.

Stevens, B. H., \& Craig L. M. (1980). A critical review of the literature on shift-share as a forecasting technique. Journal of Regional Science. 20(4), 419-437. 